\title{
PENGEMBANGAN MEDIA PEMBELAJARAN UNTUK MENINGKATKAN MOTIVASI BELAJAR DAN KARAKTER SEMANGAT KEBANGSAAN SISWA KELAS V SD
}

\author{
Abiy Risabethe ${ }^{1}$, Budi Astuti ${ }^{2}$ \\ Program Pascasarjana Universitas Negeri Yogyakarta \\ email: abiy.0408@gmail.com ${ }^{1}$, budi_astuti@uny.ac.id ${ }^{2}$
}

\begin{abstract}
Abstrak: Penelitian ini bertujuan menghasilkan media pembelajaran berupa video animasi yang layak dan untuk meningkatkan motivasi belajar dan karakter semangat kebangsaan siswa kelas V sekolah dasar se-Kecamatan Piyungan, Bantul. Penelitian dan Pengembangan (R\&D) ini menggunakan langkah-langkah pengembangan menurut Borg \& Gall, tetapi desain pengembangan video animasi hanya meliputi 9 langkah, yaitu (1) pengumpulan informasi, (2) perencanaan, (3) pengembangan produk awal, (4) uji coba lapangan awal, (5) revisi produk awal, (6) uji coba lapangan utama, (7) revisi produk, (8) uji coba lapangan operasional, dan (9) revisi produk akhir. Hasil penelitian menunjukkan bahwa media video animasi ini layak digunakan menurut ahli materi dan ahli media dengan kategori "baik". Produk yang dikembangkan juga terbukti efektif meningkatkan motivasi belajar dan karakter semangat kebangsaan siswa kelas V SD se-Kecamatan Piyungan Bantul. Rata-rata skor motivasi belajar dan karakter semangat kebangsaan pada kelas eksperimen lebih tinggi daripada kelas kontrol.
\end{abstract}

Kata Kunci : media, video animasi, motivasi belajar, karakter, semangat kebangsaan.

\section{DEVELOPING LEARNING MEDIA TO ENHANCE THE LEARNING MOTIVATION AND NATIONALISM CHARACTER OF THE $5^{\text {th }}$ GRADE STUDENTS OF ELEMENTARY SCHOOLS}

\begin{abstract}
This research aims to produce an animation video media that is feasible and effective for increasing the learning motivation and nationalism character of the $5^{\text {th }}$ grade students of elementary schools in Kecamatan Piyungan, Bantul. This research is a research and development study from Borg \& Gall model, but the design of an animation video consists of only nine steps, including (1) information collection, (2) planning, (3) preliminary product development, (4) preliminary field testing, (5) main product revision, (6) main field testing, (7) operational product revision, (8) operational field testing, and (9) final product revision. The results are as follows the developed animation video media is fit use according to the material expert and media expert, which is in a "good" category. The developed animation video media is effective for increasing the learning motivation and nationalism character of the $5^{\text {th }}$ grade students of elementary schools in Kecamatan Piyungan, Bantul. The average score of learning motivation and nationalism character in the experimental class which is higher than that of the control class.
\end{abstract}

Keywords: animation video media, learning motivation, nationalism character

\section{PENDAHULUAN}

Guru memiliki peran yang sangat penting dalam pelaksanaan pendidikan. Salah satu peran guru yaitu menumbuhkan motivasi belajar siswa. Motivasi yang tumbuh dalam diri siswa mampu membangun sistem pembelajaran yang lebih bermakna dan tentu akan mempengaruhi prestasi belajar siswa. Oleh karena itu, dalam penyelenggaraan pendidikan, guru tidak hanya mempertimbangkan aspek teknis saja namun 
juga perlu memperhatikan aspek psikologis siswa.

Aspek psikologis siswa perlu disiapkan sebaik mungkin agar proses belajar menjadi bermakna (meaningful learning) dan menyenangkan bagi siswa. Motivasi belajar akan mengoptimalkan potensi siswa. Oleh karena itu, guru perlu menciptakan situasi belajar yang kondusif yang memungkinkan siswa dapat belajar dengan baik.

Berdasarkan hasil observasi dan wawancara tanggal 1-3 Juli 2015 pada siswa kelas V SD se-Kecamatan Piyungan, diketahui bahwa motivasi belajar siswa tergolong rendah. Hal ini ditandai dengan perhatian siswa yang tidak fokus pada pembelajaran di kelas. Siswa lebih banyak mencurahkan perhatian pada teman sebangku bahkan sibuk dengan aktivitasnya sendiri. Siswa juga mudah menyerah saat mendapatkan tugas yang dianggap sulit, bahkan mereka kurang berusaha dalam menyelesaikan tugas tersebut. Salah satu penyebab dari rendahnya motivasi belajar siswa yaitu guru belum memanfaatkan media pembelajaran yang menarik dan sesuai dengan kebutuhan pada mata pelajaran tertentu.

Pemahaman guru terhadap kondisi psikologis siswa akan membawa guru untuk mengembangkan media pembelajaran yang dapat meningkatkan motivasi belajarnya. Apabila guru mampu merancang media pembelajaran yang tepat maka siswa akan termotivasi untuk fokus pada aktivitas belajarnya. Dengan demikian, pemahaman siswa terhadap materi akan meningkat sehingga tujuan pembelajaran pun tercapai.

Tidak hanya mengedepankan pada pemahaman materi saja, saat ini pendidikan juga menekankan pada pembentukan karakter siswa. Di sekolah dasar, pendidikan karakter terintegrasi ke dalam muatan pelajaran. Pelaksanaannya pada satuan pendidikan telah teridentifikasi 18 nilai yang bersumber dari agama, Pancasila, budaya, dan tujuan pendidikan nasional. Salah satu karakter yang wajib ditumbuhkembangkan pada generasi muda adalah karakter semangat kebangsaan.

Rendahnya karakter semangat kebangsaan terjadi pada siswa kelas V sekolah dasar se-Kecamatan Piyungan Bantul. Hasil observasi dan wawancara menerangkan bahwa saat upacara bendera berlangsung, petugas paduan suara tidak khidmat dalam menyanyikan lagu, bahkan diselingi dengan gurauan. Pengetahuan siswa terhadap perjuangan para pahlawan juga sangat kurang. Berdasarkan informasi yang diperoleh dari guru kelas $\mathrm{V}$, siswa belum dapat memahami sejarah kemerdekaan bangsa Indonesia begitupun tokoh-tokoh yang berjasa memperjuangkan dan mempertahankan kemerdekaan. Hal ini nampak sekali saat siswa kesulitan dalam menyebutkan nama-nama pahlawan meskipun foto tersebut terpajang di dinding kelas. Selain itu, diketahui pula bahwa siswa enggan dalam menjalankan perannya sebagai petugas upacara. Hubungan antarsiswa juga belum menunjukkan sikap saling menghargai dan menghormati.

Upaya guru dalam meningkatkan motivasai belajar dan penanaman karakter semangat kebangsaan pada diri siswa tidak lepas dari kegiatan pembelajaran. Oleh karena itu, guru haruslah berinovasi dengan mengembangkan media pembelajaran yang menarik dan efektif sebagai syarat keberhasilan proses pembelajaran. Guru wajib memfasilitasi kebutuhan siswa dalam belajar agar mampu mengingat dan menyimpan informasi dengan cepat dan mudah diingat. Guru memerlukan media yang berfungsi untuk menjembatani materi yang abstrak bagi siswa agar menjadi lebih konkret.

Selama ini siswa masih belajar dengan menggunakan media seperti peta dan gambar diam. Sementara itu, sekolah dasar di Kecamatan Piyungan telah memiliki sarana teknologi yang menunjang proses pembelajaran berupa laptop dan LCD. Guru juga telah menguasai keterampilan dalam mengoperasikan teknologi tersebut. Akan tetapi sampai saat ini pemanfaatannya masih belum optimal. LCD yang digunakan hanya menampilkan powerpoint yang berisi tulisantulisan dengan sedikit gambar.

Penggunaan teknologi yang belum optimal tersebut berimbas secara langsung kepada siswa. Siswa masih belum mampu memahami materi secara penuh dikarenakan materi yang disampaikan belum mampu menarik perhatian siswa. Siswa lebih banyak diberi tugas untuk menghafal materi pelajaran, sehingga pembelajaran menjadi membosankan, tidak berkesan, dan kurang bermakna. Tidak mengherankan apabila motivasi belajar siswa terhadap materi "Masa Penjajahan Belanda" menjadi rendah. Motivasi belajar yang rendah akan mengakibatkan 
tujuan pembelajaran yang diharapkan tidak dapat tercapai secara penuh.

Salah satu fungsi media di sini adalah menyampaikan pesan agar tidak terlalu verbalistik. Penggunaan media video saat ini menjadi alternatif dalam penyampaian materi oleh guru. Namun, di sekolah dasar seKecamatan Piyungan belum pernah mengembangkan video animasi pada mata pembelajaran IPS khususnya materi "Masa Penjajahan Belanda". Oleh karena itu, media pembelajaran yang sesuai untuk menggambarkan peristiwa yang telah lalu dapat melalui rekaman video, film, foto, dan slide. Pada penelitian ini media yang dikembangkan adalah video animasi.

Video animasi merupakan rangkaian gambar mengalami perubahan gerak atau posisi. Unsur gambar dengan gerak sederhana berusaha mengilustrasikan tokoh-tokoh dan peristiwa sejarah dan membuat objek yang bergerak kelihatan lebih hidup. Hal ini sajalan dengan pendapat Slavin (2009: 145) bahwa motivasi intrinsik untuk mempelajari sesuatu dapat ditingkatkan menggunakan bahan dan cara yang menarik seperti penggunaan film, pengajar tamu, peragaan, dan seterusnya. Pemanfaatan video animasi diharapkan mampu meningkatkan motivasi belajar siswa dengan menyajikan unsur audio dan visual yang menarik.

Unsur-unsur animasi dapat mempertahankan perhatian siswa. Karakter tokoh yang digambarkan dalam video serta alur cerita yang runtut akan dapat menyampaikan pesan yang mampu membangun karakter semangat kebangsaan dalam diri siswa. Hal ini sesuai dengan prinsip pengembangan nilai karakter pada tingkat satuan pendidikan yaitu mengintegrasikan ke dalam muatan pelajaran. Penelitian ini memfokuskan pada pengembangan media video animasi pada materi "Masa Penjajahan Belanda" untuk meningkatkan motivasi belajar dan karakter semangat kebangsaan siswa kelas V sekolah dasar se-Kecamatan Piyungan.

\section{METODE}

Model Pengembangan

Model yang digunakan adalah model pengembangan menurut Borg \& Gall (1983: 775). Namun penelitian ini hanya sampai tahap kesembilan, yaitu: (1) pengumpulan informasi, (2) perencanaan, (3) pengembangan produk awal, (4) uji coba lapangan awal, (5) revisi produk awal, (6) uji coba lapangan utama, (7) revisi produk, (8) uji coba lapangan operasional, dan (9) revisi produk akhir.

\section{Desain Uji coba Produk}

Uji coba produk terdiri dari tiga tahap yaitu uji coba lapangan awal, uji coba lapangan utama, dan uji coba lapangan operasional. Sebelum uji coba produk, perangkat pembelajaran ini divalidasi oleh ahli materi dan ahli media kemudian direvisi. Subyek uji coba dalam penelitian ini yaitu: siswa kelas V SD se-Kecamatan Piyungan Bantul. Kelas V SD Jombor sebagai kelas uji coba lapangan awal, dengan subyek sebanyak 3 siswa, dan uji coba lapangan utama sebanyak 9 siswa. Kelas V SD Bintaran sebagai kelas eksperimen dengan jumlah siswa 32 dan kelas V SD 1 Cepokojajar sebagai kelas kontrol sebanyak 22 siswa.

Teknik dan Instrumen pengumpulan data

Teknik pengumpulan data yang digunakan dalam penelitian ini adalah observasi sistematis dan tidak sistematis, wawancara terstruktur dan semi tersetruktur, skala (rating scale), dan validasi ahli (expert judgement). Sedangkan instrumen yang digunakan pada penelitian ini adalah pedoman wawancara kepada guru dan siswa, lembar penilaian produk, pedoman observasi aktivitas belajar siswa, skala mengukur motivasi belajar, skala karakter semangat kebangsaan, dan pedoman observasi karakter semangat kebangsaan.

\section{Teknik Analisis Data}

Analisis data terdiri atas dua jenis, yaitu analisis data kualitatif dan kuantitatif. Data kualitatif diperoleh dari data hasil observasi, wawancara, saran dari validasi ahli. Data dianalisis kemudian dideskripsikan secara kualitatif sehubungan dengan pengembangan media video animasi.

Data kuantitatif diperoleh dari skor penilaian ahli, skor motivasi belajar, dan skor karakter semangat kebangsaan. Data berupa skor dikonversikan berdasarkan Tabel 1 tentang Konversi Nilai (Widoyoko, 2014: 236) berikut. 
Tabel 1. Konversi Skor Skala Lima

\begin{tabular}{ccc}
\hline Interval Skor & Nilai & Kategori \\
\hline $\mathrm{X}>\mathrm{Xi}+1,8 \times \mathrm{SBi}$ & $\mathrm{A}$ & Sangat Baik \\
$\mathrm{X}+0,6 \times \mathrm{SBi}<\mathrm{X} \leq \mathrm{Xi}+1,8 \times \mathrm{SBi}$ & $\mathrm{B}$ & Baik \\
$\mathrm{X}-0,6 \times \mathrm{SBi}<\mathrm{X} \leq \mathrm{Xi}+0,6 \times \mathrm{SBi}$ & $\mathrm{C}$ & Cukup \\
$\mathrm{X}-1,8 \times \mathrm{SBi}<\mathrm{X} \leq \mathrm{Xi}-0,6 \times \mathrm{SBi}$ & $\mathrm{D}$ & Kurang \\
$\mathrm{X}<\mathrm{Xi}-1,8 \times \mathrm{SBi}$ & $\mathrm{E}$ & Sangat Kurang \\
\hline
\end{tabular}

Keterangan:

$\mathrm{Xi} \quad$ : Rata-rata Ideal $=1 / 2$ (skor
maksimum + skor minimum ideal)
$\mathrm{SBi} \quad$ : Simpangan Baku Ideal = $1 / 6$ (skor
maksimum - skor minimum)
$\mathrm{X} \quad$ skor yang diperoleh

\section{HASIL DAN PEMBAHASAN}

Studi Pendahuluan

Pada tahap studi pendahuluan dilakukan wawancara dengan guru kelas $\mathrm{V}$ di SD Jombor, SD 1 Cepokojajar, dan SD Bintaran. Berdasarkan hasil wawancara yang dilakukan pada tanggal 1-3 Juli 2015 diperoleh informasi bahwa ketiga sekolah tersebut masih melaksanakan Kurikulum Tingkat Satuan Pendidikan (KTSP) di seluruh jenjang kelas. Pada Kurikulum KTSP, kompetensi yang harus dicapai siswa dalam waktu dua semester ini sangat banyak. Beberapa materi dalam muatan pelajaran harus disampaikan secara cepat. Salah satu muatan pelajaran yang materinya sangat kompleks dan luas adalah IPS. Sedangkan metode belajar yang sering digunakan oleh siswa adalah hafalan.

Dalam memaksimalkan pembelajaran di kelas, guru menggunakan media sebagai sarana untuk menyampaikan dan memperjelas informasi seperti media gambar, globe, peta, dan sebagainya. Namun, karena materi yang terlalu kompleks dan luas ini, siswa menjadi tidak bersemangat dalam belajar sekalipun telah didukung dengan media yang sudah ada. Materi dalam muatan pelajaran IPS memang sangat khas dengan kegiatan menghafal. Sumber belajar yang digunakan siswa pun sebatas buku paket (Buku Sekolah Elektronik). Guru kelas V memberikan keterangan bahwa informasi yang dihafalkan siswa hanya bersifat sementara. Siswa mudah lupa dengan materi pelajaran. Siswa memerlukan media yang menarik. Media yang bisa menyampaikan informasi dengan cara yang menarik sehingga bermakna dan terus diingat oleh siswa. Media yang selama ini digunakan belum mampu menggugah semangat belajar siswa.

Selama pembelajaran IPS, guru menyampaikan materi pembelajaran dengan cara yang konvensional. Artinya, guru masih mendominasi perannya di kelas dalam memberikan materi menggunakan metode ceramah. Sementara itu, siswa terlihat asyik bicara dengan teman sebangku. Siswa juga nampak kurang antusias dalam memperhatikan informasi yang disampaikan guru. Guru menggunakan media gambar yang diperoleh dari internet kemudian dicetak.

Media video yang pernah disajikan oleh guru dalam pembelajaran di kelas adalah video dokumenter perjuangan para pahlawan. Video dapat didownload melalui internet. Namun video dokumenter seperti itu memiliki kualitas tampilan yang kurang bagus sehingga siswa tidak tertarik untuk menyimak. Untuk memanfaatkan secara maksimal fasilitas yang ada di sekolah, perlu dikembangkan media yang menarik berupa video animasi.

Setelah media video animasi materi "Masa Penjajahan Belanda" dikembangkan, tahap selanjutnya adalah tahap validasi. Tahap validasi ini berfungsi untuk memberikan penilaian terhadap produk yang dikembangkan. Penilaian pada produk ini terdiri dari dua hal yaitu materi dan media. Validasi materi dilakukan oleh ahli materi pembelajaran sedangkan validasi media dilakukan oleh ahli media pembelajaran. Tabel 2 berikut ini adalah hasil penilaian produk oleh ahli materi dan media.

Tabel 2. Hasil Penilaian Produk oleh Ahli Materi dan Media

\begin{tabular}{cccc}
\hline Aspek Penilaian & Skor & Nilai & Kategori \\
\hline Materi & 59 & B & Baik \\
Media & 40 & B & Baik \\
\hline
\end{tabular}

Berdasarkan Tabel 2 dapat dilihat hasil penilaian yang diperoleh dari validasi ahli materi adalah 59. Dari skor tersebut apabila dikonversikan maka predikat yang diperoleh adalah B yaitu masuk kategori baik. Sedangkan hasil penilaian dari validasi ahli media mendapatkan skor 40. Dari skor tersebut apabila dikonversikan maka predikat yang diperoleh adalah B dengan kategori baik.

Hasil Uji coba Lapangan Awal

Uji coba lapangan awal dilakukan pada hari Senin, tanggal 13 Januari 2016 di SD 
Jombor Piyungan dengan melibatkan 3 siswa. Siswa dipilih secara acak berdasarkan tingkat kemampuannya (rendah, sedang, dan tinggi). Berikut ini adalah hasil dari uji coba lapangan awal.

\section{Respons Siswa}

Respons siswa dan guru diperoleh melalui kegiatan wawancara. Berdasarkan hasil wawancara, siswa merasa tertarik dengan adanya media video animasi. Sebelumnya siswa belum pernah menggunakan media video saat pembelajaran IPS. Biasanya media yang digunakan adalah peta, globe, dan print out gambar. Siswa merasa terbantu dalam memahami materi dengan melihat video animasi. Tokoh-tokoh pahlawan yang digambarkan dalam video animasi sudah cukup sesuai. Animasi latar (background) menegaskan imajinasi siswa tentang situasi pada masa penjajahan Belanda.

\section{Respons Guru}

Hasil wawancara menyebutkan bahwa guru tidak merasa kesulitan dalam mengoperasikan media video animasi. Guru merasa lebih mudah memberikan gambaran kepada siswa tentang situasi masa penjajahan Belanda. Siswa nampak begitu ingin tahu dan serius menyaksikan tayangan video animasi. Tugas-tugas yang diberikan oleh guru dapat diselesaikan dengan baik. Guru juga menilai karakter semangat kebangsaan siswa mengalami peningkatan. Hal ini terlihat dari kerjasama yang kompak dalam kelompok belajar. Pengetahuan siswa tentang tokohtokoh pahlawan semakin bertambah. Yang semula siswa hanya mampu menyebutkan tokoh pahlawan dari satu daerah, setelah menyaksikan video animasi materi "Masa Penjajahan Belanda" siswa dapat menyebutkan tokoh pahlawan dari daerah yang lain.

\section{Motivasi Belajar}

Hasil uji coba lapangan awal bahwa menunjukkan satu siswa memiliki skor motivasi belajar 76 dengan kategori baik dan dua siswa memiliki skor motivasi belajar 80 dan 85 dengan kategori sangat baik. Rata-rata motivasi belajar pada uji coba awal adalah 78 .
Hasil lengkapkanya bisa dilihat pada tabel 3 berikut.

Tabel 3. Hasil Skala Motivasi Belajar Siswa pada Uji coba Lapangan Awal

\begin{tabular}{ccccc}
\hline No. & Nama & Skor & Nilai & Kategori \\
\hline 1 & DNH & 80 & A & Sangat Baik \\
2 & UCA & 76 & B & Baik \\
3 & AHS & 85 & A & Sangat Baik \\
\hline & Jumlah skor & $\mathbf{2 4 1}$ & & \\
& Rata-rata & $\mathbf{7 8}$ & B & Baik \\
\hline
\end{tabular}

\section{Karakter Semangat Kebangsaan}

Karakter semangat kebangsaan diukur dengan menggunakan skala dan lembar observasi. Hasil pengukuran menggunakan skala menunjukkan bahwa ketiga siswa memiliki nilai karakter semangat kebangsaan A dengan kategori sangat baik. Hasil selengkapnya tentang karakter semangat kebangsaan dapat dilihat pada tabel 4 berikut.

Tabel 4. Hasil Skala Karakter Semangat Kebangsaan Siswa pada Uji coba Lapangan Awal

\begin{tabular}{ccccc}
\hline No. & Nama & Skor & Nilai & Kategori \\
\hline 1 & DNH & 53 & A & Sangat Baik \\
2 & UCA & 55 & A & Sangat Baik \\
3 & AHS & 53 & A & Sangat Baik \\
\hline \multicolumn{2}{c}{ Jumlah skor } & $\mathbf{1 6 1}$ & & \\
Rata-rata & $\mathbf{5 3 , 6 7}$ & A & Sangat Baik \\
\hline
\end{tabular}

Sedangkan hasil observasi pada tiga siswa menunjukkan bahwa karakter semangat kebangsaan siswa mendapat nilai B dengan kategori baik. Hasil observasi selengkapnya bisa dilihat pada tabel 5 berikut.

Tabel 5. Hasil Observasi Karakter Semangat Kebangsaan Siswa pada Uji coba Lapangan Awal

\begin{tabular}{ccccc}
\hline No. & Nama & Skor & Nilai & Kategori \\
\hline 1 & DNH & 15 & A & Sangat Baik \\
2 & UCA & 13 & B & Baik \\
3 & AHS & 14 & B & Baik \\
\hline \multicolumn{2}{c}{ Jumlah Skor } & $\mathbf{4 2}$ & & Baik \\
\hline & Rata-rata & $\mathbf{1 4}$ & B & .
\end{tabular}

\section{Observasi Aktivitas Belajar Siswa}

Selain melalui kegiatan wawancara, data respons siswa juga diperoleh dari observasi terhadap aktivitas belajar siswa selama menggunakan video animasi. Hasil observasi menunjukkan bahwa ketiga siswa dapat mengikuti dengan baik. Tabel 6 berikut ini adalah data hasil observasi aktivitas belajar siswa. 
Tabel 6. Hasil Observasi Aktivitas Belajar Siswa Saat Menggunakan Video Animasi

\begin{tabular}{ccccc}
\hline No. & Nama & Skor & Nilai & Kategori \\
\hline 1 & DNH & 19 & B & Baik \\
2 & UCA & 19 & B & Baik \\
3 & AHS & 20 & B & Baik \\
\hline \multicolumn{2}{c}{ Jumlah Skor } & $\mathbf{3 8}$ & & \\
Rata-rata & $\mathbf{1 9 , 3 3}$ & B & Baik \\
\hline
\end{tabular}

Uji coba Lapangan Utama

Uji coba lapangan utama dilakukan pada hari Senin, tanggal 20 Januari 2016 di SD Jombor Piyungan dengan melibatkan 9 siswa. Siswa yang ikut dalam uji coba lapangan utama ini berbeda dengan siswa yang ikut dalam uji coba lapangan awal. Siswa dipilih secara acak berdasarkan tingkat kemampuannya yaitu siswa berkemampuan rendah, sedang, dan tinggi.

\section{Respons Siswa}

Berdasarkan hasil wawancara dengan siswa, video animasi materi "Masa Penjajahan Belanda" sangat menarik dan tidak membosankan. Siswa merasa sangat terbantu dalam mempelajari materi IPS. Tanggapan siswa terhadap pembelajaran dengan video animasi adalah bahwa video animasi ini bagus dan memperjelas materi "Masa Penjajahan Belanda". Materi yang dibaca siswa di buku terasa lebih nyata saat disajikan ke dalam bentuk animasi.

\section{Respons Guru}

Hasil wawancara dengan guru menyebutkan bahwa selama pembelajaran menggunakan media video animasi, siswa nampak bersemangat saat menjawab pertanyaan yang ada dalam video animasi. Biasanya siswa bergurau pada saat guru menjelaskan materi pelajaran. Namun hal itu berbeda saat siswa melihat video animasi, siswa nampak serius dan bersungguh-sungguh menyimak dan memperhatikan. Konsentrasi terfokus pada tampilan video. Hal ini dibuktikan dengan suasana kelas yang kondusif dan relatif tenang.

Siswa semakin bersungguh-sungguh saat mengerjakan tugas secara berkelompok. Antarsiswa sudah saling menghargai terutama saat berdiskusi dan menyampaikan pendapat. Kerukunan antarsiswa terjaga dengan baik, baik saat pembelajaran berlangsung maupun di luar kelas.

\section{Motivasi Belajar}

Motivasi belajar dari sembilan siswa pada uji coba lapangan utama ini menunjukkan bahwa tujuh siswa memperoleh nilai A dengan kategori sangat baik. Sedangkan dua siswa mendapatkan nilai $\mathrm{B}$ dengan kategori baik. Hasil selengkapnya bisa dilihat pada tabel 7 berikut.

Tabel 7. Hasil Skala Motivasi Belajar Siswa pada Uji coba Lapangan Utama

\begin{tabular}{|c|c|c|c|c|}
\hline No. & Nama & Skor & Nilai & Kategori \\
\hline 1 & LA & 80 & A & Sangat Baik \\
\hline 2 & ERE & 77 & B & Baik \\
\hline 3 & ABS & 80 & A & Sangat Baik \\
\hline 4 & $\mathrm{RP}$ & 81 & A & Sangat Baik \\
\hline 5 & FAM & 79 & A & Sangat Baik \\
\hline 6 & HHW & 78 & B & Baik \\
\hline 7 & $\mathrm{AH}$ & 79 & A & Sangat Baik \\
\hline 8 & NRF & 80 & A & Sangat Baik \\
\hline 9 & NF & 82 & A & Sangat Baik \\
\hline \multirow{2}{*}{\multicolumn{2}{|c|}{ Jumlah skor }} & 716 & & \\
\hline & & 79,56 & & Sangat Baik \\
\hline
\end{tabular}

\section{Karakter Semangat Kebangsaan}

Hasil uji coba lapangan utama menunjukkan bahwa empat siswa memperoleh nilai B dengan kategori baik. Sedangkan lima siswa memperoleh nilai A dengan kategori sangat baik. Rata-rata skor 51,56 menunjukkan bahwa karakter semangat kebangsaan siswa sangat baik. Hasil selengkapnya dapat dilihat pada tabel 8 berikut.

Tabel 8. Hasil Skala Karakter Semangat Kebangsaanpada Uji coba Lapangan Utama

\begin{tabular}{ccccc}
\hline No. & Nama & Skor & Nilai & Kategori \\
\hline 1 & LA & 52 & A & Sangat Baik \\
2 & ERE & 53 & A & Sangat Baik \\
3 & ABS & 54 & A & Sangat Baik \\
4 & RP & 51 & B & Baik \\
5 & FAM & 52 & A & Sangat Baik \\
6 & HHW & 50 & B & Baik \\
7 & AH & 49 & B & Baik \\
8 & NRF & 51 & B & Baik \\
9 & NF & 52 & A & Sangat Baik \\
\hline \multicolumn{2}{r}{ Jumlah skor } & $\mathbf{4 6 4}$ & & Sangat Baik \\
Rata-rata & $\mathbf{5 1 , 5 6}$ & &
\end{tabular}

Rata-rata skor hasil observasi karakter semangat kebangsaan kesembilan siswa adalah 13,1. Rata-rata tersebut memperoleh nilai $\mathrm{B}$ dan masuk pada kategori baik. Perhatikan tabel 9 berikut. 
Tabel 9. Hasil Observasi Karakter Semangat Kebangsaan Siswa pada Uji coba Lapangan Utama

\begin{tabular}{ccccc}
\hline \multirow{2}{*}{ No. } & \multirow{2}{*}{ Variabel } & \multirow{2}{*}{ Nilai } & \multicolumn{2}{c}{ Observasi } \\
& Karakter & Rata-rata & 10,91 & Akhir \\
\hline \multirow{2}{*}{1} & Semangat & Tertinggi & 11,41 \\
& Kebangsaan & Terendah & 9,5 & 13 \\
& & & & 9,5 \\
\hline
\end{tabular}

\section{Observasi Aktivitas Belajar Siswa}

Hasil observasi aktivitas belajar menunjukkan tiga siswa memperoleh skor 21 dengan nilai A termasuk kategori sangat baik. Terdapat empat siswa mendapatkan skor 20 dengan nilai B termasuk kategori baik. Sedangkan dua siswa lainnya memperoleh skor 19 dengan nilai B termasuk pada kategori baik. Setelah dihitung rata-rata skor kesembilan siswa diperoleh skor 20,11 dengan nilai A termasuk kategori sangat baik. Perhatikan tabel 10 berikut!

Tabel 10. Hasil Observasi Aktivitas Belajar Siswa Saat Menggunakan Video Animasi

\begin{tabular}{ccccc}
\hline No. & Nama & Skor & Nilai & Kategori \\
\hline 1 & LA & 20 & B & Baik \\
2 & ERE & 19 & B & Baik \\
3 & ABS & 21 & A & Sangat Baik \\
4 & RP & 20 & B & Baik \\
5 & FAM & 21 & A & Sangat Baik \\
6 & HHW & 21 & A & Sangat Baik \\
7 & AH & 19 & B & Baik \\
8 & NRF & 20 & B & Baik \\
9 & NF & 20 & B & Baik \\
\hline \multicolumn{7}{c}{ Jumlah Skor } & $\mathbf{1 8 1}$ & & \\
& Rata-rata & $\mathbf{2 0 , 1 1}$ & A & Sangat Baik \\
\hline
\end{tabular}

Uji coba Lapangan Operasional

Uji coba lapangan operasional dilakukan di SD Bintaran dengan subjek uji coba sebanyak 32 siswa kelas V sebagai kelas eksperimen dan di SD 1 Cepokojajar dengan subjek uji coba sebanyak 22 siswa kelas V sebagai kelas kontrol.

\section{Kelas Kontrol}

\section{Motivasi Belajar}

Data hasil pretest dan posttest kelas kontrol diambil dari 22 siswa kelas V SD 1 Cepokojajar. Data diperoleh dari tes yang dilakukan sebelum dan sesudah pembelajaran. Pada kelas kontrol media yang digunakan guru di kelas adalah yang biasa digunakan dalam pembelajaran (gambar diam). Perhatikan tabel 11 berikut!
Tabel 11. Hasil Pretest dan Posttest Motivasi Belajar Siswa pada Kelas Kontrol

\begin{tabular}{ccccc}
\hline \multirow{2}{*}{ No. } & \multirow{2}{*}{ Variabel } & \multirow{2}{*}{ Nilai } & Pretest & Posttest \\
\hline \multirow{2}{*}{1} & \multirow{2}{*}{ Motivasi } & Rata-rata & 76,73 & 77,18 \\
& Belajar & Tertinggi & 82 & 82 \\
& & Terendah & 71 & 71 \\
\hline
\end{tabular}

Rata-rata nilai pretest motivasi belajar siswa di kelas kontrol adalah 76,73. Setelah dilakukan kegiatan pembelajaran seperti biasa yaitu dengan menggunakan peta dan gambar (diam), nilai rata-rata yang diperoleh pada posttest adalah 77,18 . Pada pretest nilai tertinggi yang diperoleh adalah 82 dan nilai terendah adalah 71 . Sedangkan pada posttest nilai tertinggi yang diperoleh adalah 82 dan nilai terendah adalah 71 .

\section{Karakter Semangat Kebangsaan}

Rata-rata nilai pretest karakter semangat kebangsaan siswa di kelas kontrol adalah 50,32. Setelah dilakukan kegiatan pembelajaran menggunakan media peta dan gambar (diam), rata-rata nilai posttest menjadi 51. Pada pretest nilai tertinggi yang diperoleh adalah 55 dan nilai terendah adalah 43 . Sedangkan pada posttest nilai tertinggi yang diperoleh adalah 54 dan nilai terendah adalah 46. Perhatikan tabel 12 berikut!

Tabel 12. Hasil Pretest dan Posttest Karakter Semangat Kebangsaan pada Kelas Kontrol

\begin{tabular}{ccccc}
\hline \multirow{2}{*}{ No. } & \multirow{2}{*}{ Variabel } & \multirow{2}{*}{ Nilai } & \multicolumn{2}{c}{ Tes } \\
& & & Pretest & Posttest \\
\hline \multirow{2}{*}{1} & Karakter & Rata-rata & 50,32 & 51 \\
& Semangat & Tertinggi & 55 & 54 \\
& Kebangsaan & Terendah & 43 & 46 \\
\hline
\end{tabular}

Nilai rata-rata pada observasi sebelum pembelajaran (awal) adalah 10,91 masuk pada kategori cukup. Setelah dilakukan pembelajaran menggunakan media yang biasa digunakan guru, nilai rata-rata menjadi 11,41 masuk pada kategori baik. Nilai tertinggi pada observasi awal adalah 12 dan nilai terendah adalah 9,5. Sementara itu, nilai tertinggi pada observasi akhir adalah 13 dan nilai terendah adalah 9,5. Perhatikan tabel 13 berikut. 
Tabel 13. Hasil Observasi Karakter Semangat Kebangsaan pada Kelas Kontrol

\begin{tabular}{ccccc}
\hline No. & Nama & Skor & Nilai & Kategori \\
\hline 1 & LA & 13 & B & Baik \\
2 & ERE & 12 & B & Baik \\
3 & ABS & 13 & B & Baik \\
4 & RP & 12 & B & Baik \\
5 & FAM & 14 & B & Baik \\
6 & HHW & 14 & B & Baik \\
7 & AH & 13 & B & Baik \\
8 & NRF & 13 & B & Baik \\
9 & NF & 14 & B & Baik \\
\hline \multicolumn{7}{r}{ Total Skor } & $\mathbf{1 1 8}$ & & Baik \\
& Rata-rata & $\mathbf{1 3 , 1 1}$ & B & \\
\hline
\end{tabular}

Kelas Eksperimen

\section{Motivasi Belajar}

Data hasil pretest dan posttest di kelas eksperimen diambil dari 32 siswa kelas V SD Bintaran. Data diperoleh dari tes yang dilakukan sebelum dan sesudah kegiatan pembelajaran dengan menggunakan media video animasi materi "Masa Penjajahan Belanda". Perhatikan tabel 14 berikut!

Tabel 14. Hasil Pretest dan Posttest Motivasi Belajar Siswa pada Kelas Eksperimen

\begin{tabular}{ccccc}
\hline \multirow{2}{*}{ No. } & \multirow{2}{*}{ Variabel } & Nilai & \multicolumn{2}{c}{ Tes } \\
& & & Pretest & Posttest \\
\hline \multirow{2}{*}{1} & Motivasi & Rata-rata & 77,41 & 81,16 \\
& Belajar & Tertinggi & 83 & 87 \\
& & Terendah & 71 & 75 \\
\hline
\end{tabular}

Rata-rata nilai pretest pada motivasi belajar siswa di kelas eksperimen 77,41. Setelah dilakukan kegiatan pembelajaran menggunakan media video animasi, rata-rata nilai posttest menjadi 81,16 . Pada pretest nilai tertinggi yang diperoleh adalah 83 dan nilai terendah adalah 71 . Sedangkan pada posttest nilai tertinggi yang diperoleh adalah 87 dan nilai terendah adalah 75 .

\section{Karakter Semangat Kebangsaan}

Rata-rata nilai pretest pada karakter semangat kebangsaan siswa di kelas eksperimen 49,94. Setelah dilakukan kegiatan pembelajaran menggunakan media video animasi, rata-rata nilai posttest menjadi 54,5. Pada pretest nilai tertinggi yang diperoleh adalah 56 dan nilai terendah adalah 42 . Sedangkan pada posttest nilai tertinggi yang diperoleh adalah 58 dan nilai terendah adalah 49. Perhatikan tabel 15 berikut.
Tabel 15. Hasil Pretest dan Posttest Karakter Semangat Kebangsaan pada Kelas Eksperimen

\begin{tabular}{ccccc}
\hline \multirow{2}{*}{ No. } & \multirow{2}{*}{ Variabel } & Nilai & \multicolumn{2}{c}{ Tes } \\
& Karetest & Posttest \\
\hline \multirow{2}{*}{1} & Karakter & Rata-rata & 49,94 & 54,5 \\
& Semangat & Tertinggi & 56 & 58 \\
& Kebangsaan & Terendah & 42 & 49 \\
\hline
\end{tabular}

Sedangkan hasil observasi karakter semangat kebangsaan menunjukkan bahwa nilai rata-rata observasi sebelum pembelajaran menggunakan media video animasi adalah 11,23. Setelah pembelajaran menggunakan media video animasi, rata-rata nilai meningkat menjadi 12,72 . Nilai tertinggi pada observasi awal adalah 12 dan nilai terendah adalah 9,5. Sedangkan nilai tertinggi pada observasi akhir adalah 14 dan nilai terendah 10,5. Perhatikan tabel 16 berikut!

Tabel 16. Hasil Observasi Karakter Semangat Kebangsaan pada Kelas Eksperimen

\begin{tabular}{ccccc}
\hline \multirow{2}{*}{ No. } & \multirow{2}{*}{ Variabel } & \multirow{2}{*}{ Nilai } & \multicolumn{2}{c}{ Observasi } \\
& & Awal & Akhir \\
\hline \multirow{2}{*}{1} & Karakter & Rata-rata & 11,23 & 12,72 \\
& Semangat & Tertinggi & 12 & 14 \\
& Kebangsaan & Terendah & 9,5 & 10,5 \\
\hline
\end{tabular}

\section{Respons Guru}

Hasil wawancara dengan guru kelas V di kelas eksperimen menunjukkan bahwa guru tidak mengalami kesulitan saat menayangkan video animasi di kelas. Format file video adalah MP4 yang dapat diputar dengan menggunakan program video player pada laptop. Guru merasa bahwa lebih mudah belajar menggunakan video animasikarena video ini memberikan gambaran dari materi yang ada di buku. Animasi di dalam video lebih mengena pada siswa daripada hanya menggunakan gambar.

Siswa lebih termotivasi belajarnya dengan video ini karena video animasi ini masih hal yang baru bagi siswa. Selama ini siswa yang belajar materi IPS dengan dibantu media gambar diam belum dapat belajar secara optimal. Namun, setelah diperkenalkan dengan video animasi, siswa menjadi lebih bersemangat dalam belajar. Tidak hanya itu, siswa juga dapat mencontoh karakter para pahlawan yang digambarkan dalam animasi video. Sedikit demi sedikit muncul karakter semangat kebangsaan dalam diri siswa yang ditunjukkan melalui pergaulan rukun dengan siswa lainnya serta kesungguhan siswa dalam melaksanakan tanggung jawabnya sebagai pelajar yaitu dengan belajar. 


\section{Respons Siswa}

Hasil wawancara menyebutkan bahwa siswa merasa sangat senang belajar dengan melihat tayangan video animasi. Siswa merasa lebih mudah dalam memahami materi IPS apabila disajikan ke dalam bentuk animasi. Daripada media gambar, video animasi ini lebih menarik dan memperjelas materi yang ada di buku pelajaran.

\section{Observasi Aktivitas Belajar Siswa}

Selain wawancara, data respons siswa juga diperoleh melalui observasi aktivitas belajar selama menggunakan media video animasi. Hasil observasi terhadap aktivitas belajar siswa menunjukkan sejumlah 11 siswa yang memperoleh nilai A dengan kategori sangat baik. Sedangkan 21 siswa memperoleh nilai $\mathrm{B}$ dengan kategori baik. Perhatikan tabel 17 berikut.

Tabel 17. Hasil Observasi Aktivitas Belajar Siswa Saat Menggunakan Video Animasi

\begin{tabular}{ccccc}
\hline No. & Interval skor & Nilai & Kategori & $\begin{array}{c}\text { Jumlah } \\
\text { Siswa }\end{array}$ \\
\hline 1 & $\mathrm{X}>20$ & $\mathrm{~A}$ & Sangat Baik & 11 \\
2 & $17<\mathrm{X} \leq 20$ & $\mathrm{~B}$ & Baik & 21 \\
3 & $13<\mathrm{X} \leq 17$ & $\mathrm{C}$ & Cukup & - \\
4 & $10<\mathrm{X} \leq 13$ & $\mathrm{D}$ & Kurang & - \\
5 & $\mathrm{X}<10$ & $\mathrm{E}$ & Sangat Kurang & - \\
\hline
\end{tabular}

Hasil Uji Paired Sample t-test

\section{Motivasi Belajar}

Uji-t tidak hanya dilakukan untuk mengetahui keefektifan media video animasi pada kelas eksperimen dan kelas kontrol, melainkan juga untuk mengetahui perbedaan motivasi belajar siswa saat sebelum dan setelah menggunakan media video animasi pada kelas eksperimen. Perbandingan ini dilihat pada nilai pretest dan posttest siswa. oleh karena itu selanjutnya dilakukan uji Paired Sample t-test menggunakan program SPSS 16.0. Berikut ini adalah hipotesis yang diajukan pada Uji Paired Sample t-test.

$\mathrm{H}_{0}$ : tidak terdapat perbedaan yang signifikan pada hasil tes motivasi belajar siswa kelas eksperimen sebelum dengan sesudah menggunakan media video animasi.
$\mathrm{H}_{1} \quad$ : terdapat perbedaan yang signifikan pada hasil tes motivasi belajar siswa kelas eksperimen sebelum dengan sesudah menggunakan media video animasi.

Untuk melihat perbedaan itu apakah signifikan (secara statistik) maka dapat dilihat nilai signifikansi Paired Sample t-test. Dengan berpedoman pada nilai signifikansi 5\% atau 0,05 maka nilai signifikansi 0,000 lebih kecil dari $0,05(0,000<0,05)$ yang berarti $\mathrm{H}_{0}$ ditolak. Kesimpulannya terdapat perbedaan yang signifikan pada hasil tes motivasi belajar siswa kelas eksperimen sebelum dengan sesudah menggunakan media video animasi. Perhatikan tabel 18 berikut.

Tabel 18. Hasil Uji Paired Sample t-test pada Motivasi Belajar Siswa Kelas Eksperiman

\begin{tabular}{|c|c|c|c|c|c|}
\hline \multirow{2}{*}{ No. } & \multirow{2}{*}{ Variabel } & \multicolumn{2}{|c|}{ Rata-rata Nilai } & \multirow{2}{*}{ Sig. } & \multirow{2}{*}{ Ket. } \\
\hline & & Pretest & Posttest & & \\
\hline 1 & $\begin{array}{c}\text { Motivasi } \\
\text { Belajar }\end{array}$ & 77,4062 & 81,1562 & 0,000 & $\begin{array}{c}\mathbf{p}<\mathbf{0 , 0 5} \\
\mathrm{H}_{0} \\
\text { ditolak }\end{array}$ \\
\hline
\end{tabular}

\section{Karakter Semangat Kebangsaan}

Uji Paired Sample t-test dilakukan untuk mengetahui keefektifan media video animasi terhadap karakter semangat kebangsaan pada kelas eksperimen. Uji-t ini bertujuan untuk mengetahui perbedaan karakter semangat kebangsaan siswa saat sebelum dan setelah menggunakan media video animasi pada kelas eksperimen. Perbandingan ini dilihat pada nilai pretest dan posttest siswa. Oleh karena itu, selanjutnya dilakukan uji Paired Sample t-test menggunakan program SPSS 16.0. Berikut ini adalah hipotesis yang diajukan pada Uji Paired Sample t-test.

$\mathrm{H}_{0} \quad$ : tidak terdapat perbedaan yang signifikan pada hasil tes karakter semangat kebangsaan siswa kelas eksperimen sebelum dengan sesudah menggunakan media video animasi.

$\mathrm{H}_{1} \quad$ : terdapat perbedaan yang signifikan pada hasil tes karakter semangat kebangsaan siswa kelas eksperimen sebelum dengan sesudah menggunakan media video animasi. 
Untuk melihat perbedaan itu apakah signifikan (secara statistik) maka dapat dilihat pada nilai signifikasi pada Paired Sample ttest. Dengan berpedoman pada nilai signifikansi $5 \%$ atau 0,05 maka nilai signifikansi 0,000 lebih kecil dari $0,05(0,000<$ $0,05)$ yang berarti $\mathrm{H}_{0}$ ditolak. Kesimpulannya terdapat perbedaan yang signifikan pada hasil tes karakter semangat kebangsaan siswa kelas eksperimen sebelum dengan sesudah menggunakan media video animasi. Perhatikan tabel 19 berikut.

Tabel 19. Hasil Uji Paired Sample t-test pada Karakter Semangat Kebangsaan Siswa Kelas Eksperimen

\begin{tabular}{|c|c|c|c|c|c|}
\hline \multirow{2}{*}{ No. } & \multirow{2}{*}{ Variabel } & \multicolumn{2}{|c|}{ Rata-rata Nilai } & \multirow{2}{*}{ Signf. } & \multirow{2}{*}{ Keterangan } \\
\hline & & Pretest & Posttest & & \\
\hline 1 & $\begin{array}{c}\text { Karakter } \\
\text { Semangat } \\
\text { Kebangsaan }\end{array}$ & 49,9375 & 54,500 & 0,000 & $\begin{array}{c}\text { p }<\mathbf{0 , 0 5} \\
\mathrm{H}_{0} \text { ditolak }\end{array}$ \\
\hline
\end{tabular}

\section{Pembahasan}

Media video animasi pada materi "Masa Penjajahan Belanda" dikembangkan berdasarkan pada analisis kebutuhan (need analysis) di lapangan. Motivasi belajar dan karakter semangat kebangsaan siswa kelas $\mathrm{V}$ SD di Kecamatan Piyungan masih tergolong rendah. Salah satu penyebab rendahnya motivasi belajar siswa adalah media pembelajaran yang kurang menarik perhatian siswa. Berdasarkan studi lapangan, siswa membutuhkan media pembelajaran yang mampu menarik perhatian siswa dan dapat menanamkan nilai-nilai yang baik.

Sekolah dasar di Kecamatan Piyungan telah memiliki sarana dan prasarana yang cukup lengkap yaitu dengan adanya LCD dan proyektor. Untuk memanfaatkan secara maksimal fasilitas yang ada di sekolah, perlu dikembangkan media yang menarik yaitu media video animasi. Dalam penelitan Kahraman (2014: 27) menyebutkan bahwa salah satu cara untuk mengintensifkan pembelajaran adalah dengan media audio visual. Hal ini karena dalam media audiovisual terdapat grafis, suara, dan bentuk. Animasi menjadi salah satu produk (audio visual) yang dapat digunakan untuk meningkatkan pembelajaran. Video ini diharapkan dapat meningkatkan motivasi belajar dan karakter semangat kebangsaan siswa.

Media video animasi materi "Masa Penjajahan Belanda" termasuk media audio visual yang disajikan dalam bentuk gambar, suara, teks, musik, warna, dan gerak. Gambargambar animasi dalam video dibuat menarik dengan memadukan berbagai warna. Musik yang disajikan juga sesuai dengan konteks materi yang disajikan dan berusaha menggambarkan situasi perjuangan pada masa penjajahan Belanda. Suara pada video sudah cukup jelas didengar dalam memaparkan isi materinya. Teks penjelas juga dapat dibaca oleh siswa. Dalam penelitian Fanny \& Suardiman (2013: 6) disebutkan bahwa animasi (warna, teks, gambar, suara, dan musik) merupakan bahan penarik perhatian.

Video animasi ini dirancang dengan mempertimbangkan karakteristik siswa dan teori-teori pembelajaran. Melalui video animasi, siswa dapat membangun pengetahuan, mendukung visualisasi, dan interpretasi materi pelajaran. Video ini dirancang dengan tujuan membantu guru dalam menyampaikan informasi sehingga siswa menjadi lebih termotivasi mempelajari materi "Masa Penjajahan Belanda" dan mampu meningkatkan karakter semangat kebangsaan siswa kelas V. Hal ini sejalan dengan penelitian yang dilakukan oleh Chang \& Quintana (2006: 71) bahwa video animasi sangat mendukung proses belajar siswa terutama dalam mengkonstruksi pengetahuan.

Produk media video animasi sudah sesuai dengan standar kualitas teknologi dan media pembelajaran. Seperti yang dijelaskan oleh Smaldino, Lowther \& Russell (2008: 86) bahwa teknologi dan media yang digunakan dalam pembelajaran, harus memenuhi beberapa kriteria yaitu (1) kesesuaian dengan standar, hasil, dan tujuan; (2) informasi akurat dan terkini; (3) bahasa sesuai usia; (4) melibatkan minat dan keterlibatan; (5) kualitas teknis; (6) mudah digunakan; (7) bebas bias; dan (8) petunjuk bagi pengguna.

Data hasil uji kelayakan produk diperoleh melalui validasi ahli materi dan ahli media. Skor hasil penilaian para ahli dikonversikan ke dalam skala lima. Hasil penilaian ahli materi dan ahli media menunjukkan bahwa media video animasi ini layak sebagai media pembelajaran. Skor yang diperoleh dari ahli materi adalah 59 dengan kategori "Baik". Sedangkan skor yang diperoleh dari ahli media adalah 40 dengan kategori "Baik". Produk media video dikatakan layak digunakan jika minimal berada pada kategori "Baik". 
Pembelajaran menggunakan media video animasi dilakukan secara klasikal. Siswa memperoleh informasi tentang materi "Masa Penjajahan Belanda" dari tayangan video. Selama pembelajaran berlangsung, terdapat kegiatan tanya jawab dengan siswa melalui narator yang ada dalam video. Oleh karena itu, siswa tetap dapat terlibat dalam kegiatan pembelajaran. Dan setelah penyajian materi selesai, siswa dilibatkan secara aktif dalam penyelesaian tugas kelompok. Peran guru dalam pembelajaran menggunakan video animasi adalah dengan memberikan pertanyaan-pertanyaan yang bersifat analitis, sehingga siswa mampu menemukan sendiri nilai-nilai khususnya semangat kebangsaan yang ada dalam video animasi.

Berdasarkan uji-t yang telah dilakukan untuk mengetahui keefektifan media video animasi, diperoleh informasi bahwa produk pengembangan berupa media video animasi materi "Masa Pejajahan Belanda" dapat meningkatkan motivasi belajar dan karakter semangat kebangsaan siswa kelas V SD seKecamatan Piyungan Bantul. Hal ini dibuktikan dengan perbedaan skor rata-rata pada pretest dan posttest. Perbedaan juga dapat dilihat pada besarnya nilai signifikansi uji Paired Sample t-test pada motivasi belajar dan karakter semangat kebangsaan siswa yaitu sebesar 0,000 yang artinya terdapat perbedaan antara sebelum dan sesudah pembelajaran menggunakan media video animasi. Penelitian Astuti \& Mustadi (2014: 33) menjelaskan bahwa film animasi mampu mendorong munculnya ide-ide kreatif. Dengan adanya visualisasi berupa gambar dalam film animasi akan memberikan informasi yang lebih menarik bagi siswa.

Respons siswa dan guru pada kegiatan uji coba menunjukkan bahwa siswa dan guru merasa terbantu dengan adanya media video animasi. Secara teknis, video animasi ini mudah digunakan mengingat sarana yang ada di sekolah yang cukup terbatas. Sehingga video ini memang dirancang dapat digunakan secara klasikal. Baik siswa maupun guru, sama-sama merasa lebih tertarik belajar menggunakan video animasi daripada menggunakan media yang sebelumnya. Animasi yang disajikan jelas berbeda dengan media yang umumnya digunakan seperti print out gambar.

Penelitian dari Liying \& Tao (2013: 568) menegaskan bahwa animasi cenderung lebih baik daripada visualisasi statis (gambar diam) dalam menyampaikan pemahaman kepada siswa. Animasi memiliki potensi untuk membantu siswa memproses informasi belajar secara mendalam. Siswa lebih mudah menyimpan informasi yang disampaikan melalui gambar yang berwarna dan bergerak.

$$
\text { Video animasi materi "Masa }
$$

Penjajahan Belanda" terbukti mampu menjadi salah satu cara dalam meningkatkan motivasi belajar siswa karena penyajiannya yang menarik. Begitu pun dengan karakter semangat kebangsaan siswa, video animasi menceritakan perjuangan para pahlawan pada masa penjajahan dapat memberikan teladan (contoh) bagi siswa sehingga memiliki karakter semangat kebangsaan seperti karakter para pahlawan. Penelitian yang dilakukan Bailey, Tettegah, \& Bradley (2005: 817) menjelaskan bahwa animasi menjadi salah satu teknik untuk mengajarkan pendidikan karakter pada anak dalam lingkup yang luas (klasikal). Dengan menyajikan materi dalam bentuk teknologi (animasi), pembelajaran akan menjadi lebih menyenangkan. Pembelajaran yang menyenangkan dapat menciptakan kebermaknaan.

\section{PENUTUP}

Penelitian pengembangan ini menghasilkan produk berupa video pembelajaran. Video yang dikembangkan berupa video animasi pada materi "Masa Penjajahan Belanda". Media video animasi materi "Masa Penjajahan Belanda" terbukti layak digunakan untuk meningkatkan motivasi belajar dan karakter semangat kebangsaan siswa kelas V SD menurut ahli materi dan ahli media dengan kategori baik.

Video animasi ini terbukti efektif dalam meningkatkan motivasi belajar dan karakter semangat kebangsaan siswa kelas $\mathrm{V}$ SD. Hal ini dibuktikan dengan data hasil uji coba lapangan operasional pada kelas kontrol dan kelas eksperimen bahwa uji-t menunjukkan ada perbedaan yang signifikan dalam hal motivasi belajar dan karakter semangat kebangsaan siswa antara kelas yang menggunakan media video animasi dengan yang tidak menggunakan video animasi.

Berdasarkan simpulan mengenai pengembangan media video animasi ini, maka saran bagi guru sekolah dasar kelas $\mathrm{V}$ yaitu: (1) guru dapat menggunakan video animasi 
materi "Masa Penjajahan Belanda" sebagai salah satu alternatif media pembelajaran yang dapat meningkatkan motivasi belajar dan karakter semangat kebangsaan siswa tentunya dengan melakukan need assessment terlebih dahulu. (2) sekolah perlu memiliki sarana dan prasarana yang mendukung seperti laptop, LCD, dan juga proyektor. Apabila tidak memiliki fasilitas tersebut maka sekolah dapat menggunakan media televisi dan DVD player.

\section{UCAPAN TERIMA KASIH}

Dengan selesainya tulisan ini penulis mengucapkan terima kasih yang sebesarbesarnya kepada direktur Program Pascasarjana Universitas Negeri Yogyakarta yang telah memberikan fasilitas dan layanan dalam memperoleh bekal ilmu yang cukup sehingga akhirnya tulisan ini dapat terselesaikan. Ucapan terima kasih juga disampaikan kepada ketua dewan redaksi Jurnal Pendidikan Karakter beserta seluruh anggotanya atas dimuatnya tulisan ini pada edisi sekarang.

\section{DAFTAR PUSTAKA}

Astuti, Y., \& Mustadi, A. 2014. Pengaruh penggunaan media film animasi terhadap keterampilan menulis karangan narasi siswa kelas V SD. Jurnal Prima Edukasia, (2), 250262. doi:http://dx. doi.org/10.21831/jpe.v2i2.2723

Bailey, B. P., Tettegah, S. Y., \& Bradley, T. J. 2005. Clover: Connecting technology and character education using personally-constructed animated vignettes. Proceedings of ACM Multimedia, University of Illinois, November 2005. Urbana: University of Illinois.

Borg, W. R. \& Gall, M. D. 1983. Educational research an introduction. New York: Longman.

Chang, H. Y., \& Quintana, C. 2006. Studentgenerated animations: supporting middle school students' visualization, interpretation and reasoning of chemical phenomena. In Proceedings of the 7th International Conference on Learning Sciences, University of
Michigan, Juni 2006. Ann Arbor: University of Michigan.

Fanny, A., \& Suardiman, S. 2013. Pengembangan multimedia interaktif untuk mata pelajaran ilmu pengetahuan sosial (IPS) sekolah dasar kelas V. Jurnal Prima Edukasia, (1), 1-9.

doi:http://dx.doi.org/10.21831/jpe.v1i1 .2311

Kahraman, A. D. 2014. Animation use as an educational material and animation technique. International Conference on Communitation, Media, Technology and Design, 24-26 April 2014 di KTO Karatay University. Istambul: Karatay University.

Liying, Z., \& Tao, H. November 2013. Experimental Research on The Effectiveness of Animated Instruction. Diakses tanggal 25 Maret 2016 dari http://www.atlantispress. $\mathrm{com} / \mathrm{php} /$ paper-details. php?id= 10421.

Slavin, R. E. 2009. Psikologi pendidikan teori dan praktik (edisi kedelapan) jilid 2. Jakarta Barat: Indeks.

Smaldino, L., Lowther, D. L. \& Russel, J. D. 2008. Instructional technology and media for learning $\left(9^{\text {th }}\right.$ ed). Upper Saddle River: Pearson.

Widoyoko, E. P. 2014. Teknik penyusunan instrumen penelitian. Yogyakarta: Pustaka Pelajar. 